\title{
The Influence of Hard Skill and Soft Skill Competencies on the Competitiveness of Managerial Accounting Diploma-4 Students
}

\author{
Cening Ardina*, Luh Mei Wahyuni, Anak Agung Gde Mantra Suarjana \\ Accounting Department \\ Bali State Polytechnic \\ Badung, Indonesia \\ *ardina@pnb.ac.id, meiwahyuni@pnb.ac.id, agungsuarjana@gmail.com
}

\begin{abstract}
The research on the managerial accounting diploma-4 students of Bali State Polytechnic is aimed at analysing: (1) the industrial perception of the students' hard skill competence; (2) the industrial perception of the students' soft skill competence; (3) the industrial perception of the students' competitiveness; (4) the influence of hard skill competence on competitiveness; (5) the influence of soft skill competence on competitiveness; (6) the influence of hard skill and soft skill competence simultaneously on competitiveness; and (7) hard skill and soft skill competence integration model to increase competitiveness. The techniques used in analysing the data are qualitative and quantitative analytical techniques (multiple linear regression). The industrial perception of the students' soft skill competence is very good and the perception of the students' competitiveness is very good as well. Hard skill competence gives a positive and significant influence to the students' competitiveness. Soft skill competence gives a positive and significant influence to students' competitiveness as well. Hard skill and soft skill competence simultaneously give positive and significant influence to the students' competitiveness. To increase the competitiveness of managerial accounting diploma-4 students, the integration pattern between hard skill and soft skill competence has to complement each other, considering hard skill and soft skill competencies have to meet the needs of the industries nowadays.
\end{abstract}

Keywords-hard skill competence, soft skill competence, competitiveness

\section{INTRODUCTION}

Education plays very important role in producing human resources with appropriate amount and quality as the main supporter in development. As the competition among study programs becomes increasingly intense, it is needed to prepare the students who are ready to work, has good moral and attitude, and are highly intelligent. Entrepreneurs and society demand more graduates who are competent and ready to work, equipped with some particular abilities and competence to be applied in work field [1]. Higher education becomes a strategic sector that is expected to be able to produce qualified human resources. Likewise, the Bali State Polytechnic Accounting Department must be able to produce quality graduates. Quality graduates need to be assessed for their competencies, both hard skills and soft skills. Education directly affects knowledge, while experiences, training, and interest directly affect knowledge and skill [2]. By observing the importance of hard skill and soft skill competence, it is really needed to know the reality of the development of hard skill and soft skill competencies that are needed in the work field because these two competencies are complementary. The phenomenon that occurs in the development of hard skill competencies is more dominant than soft skill competencies. Therefore, the evaluation of the hard skills and soft skills of the managerial accounting students of the Bali State Polytechnic Accounting Department needs to be considered.

In fact, there is often a discrepancy between the higher education graduates' competence and the needs of the working world. Therefore, the orientation of higher education graduate's quality that is merely oriented to hard skill all this time needs to be changed. As well, the elements of soft skill competence development that is needed in business and industries needs to be included. The results showed that the research variables, namely hard skills, interpersonal and intrapersonal skills, both partially and simultaneously have a significant effect on performance [3]. Perceptions of IT students consider that hard skills are very important while the industry considers hard skills to be somewhat important. The study suggests that universities should enrich soft skills and hard skills into components in the curriculum [4]. Hard skills and soft skills have a significant effect on employee performance. Soft skill variable was found to be the variable with the dominant influence on employee performance [5]. Soft skill competence does not give a positive and significant influence to the performance [6]. It is found out that soft skill competence gives a positive and significant influence to the employee work performance [7].

Competence discrepancy occurs between performance and entrepreneur interests, so that cooperative education program is 
needed [8]. On the one hand, the combination of hard skill and soft skill is really needed in the working world; however, on the other hand, there is still an empirical discrepancy of the research result. Therefore, this case is interesting to be researched along with the development of phenomena that happened in the working world recently. Beside the academic and professional competencies, it is needed intrapersonal and interpersonal abilities (soft skill) as well. This research is aimed at analysing: (1) the industrial perception of the students' hard skill competence; (2) the industrial perception of the students' soft skill competence; (3) industrial perception of the students' competitiveness; (4) the influence of hard skill competence on competitiveness; (5) hard skill and soft skill competencies integration model to increase competitiveness.

\section{LITERATURE REVIEW}

Competence is an interrelation among groups of knowledge, skill, and ability needed by an individual to be effective. Hard skill is a skill for teaching that needs a context, such as work training that will help an individual to carry out his/ her job [9]. Hard skill is a basic thing that helps a worker to develop knowledge carefully in an area [10].

Soft skill is classified into six skills: communication, IT skill, numerical skill, learning skill, problem-solving skill and cooperation with others [11]. The importance of soft skill in life in college and after college, how soft skill complements hard skill, is a technical requirement at work that has to be trained [12]. The lack of soft skill competence for many bachelors results in other problems; they are the inability of the graduates to get beneficial jobs and to become important members of the communities in their working places [13]. The graduates from IT colleges show competencies in interpersonal communication, teamwork, and conflict management. Soft skill development has become a major concern in higher education [14]. Students consider the soft skill formation as an important part of education in universities [15].

Increase in employee performance in the company due to the acquisition of employee soft skills [16]. Soft skills have an impact on employee performance [17]. Hard skill and soft skill competencies give positive and significant influence to the employee performance either simultaneously or partially [18]. Hard skill and soft skill competencies are considered equally important by employers as a whole. The competencies are developed among the students before getting into the world of work. Competence is practical; it cooperates with industries to develop programs oriented to working places [19].

The term daya saing (competitiveness in Indonesian language) consists of word daya that means power, and word saing that means to achieve more than the others, different from the others in terms of quality, or has particular excellences [20]. The competitiveness of graduates referred to in this research is power and ability of the graduates in mastering and doing their work in workplaces. The competitiveness of the graduates can be measured from the process of work execution or students' performance in doing the work during the field work practice.

\section{MATERIALS AND METHOD}

The primary data source of this research is the industries where the managerial accounting diploma- 4 students do field work practice. Population in this research is all the industries in Bali province where college students do field work practice. The samples of student are taken by applying purposive sampling. To determine the number of samples, researchers use the opinion of Tabachnick and Fidell in Pallant [21] where samples for regression test is: $n>50+8 m$; where $n=$ the number of samples, $\mathrm{m}=$ the number of independent variables. Samples in this research are 100 managerial accounting diploma-4 students as respondent / research subjects.

The analytical techniques used in this research are qualitative and quantitative analytical techniques. Descriptive qualitative analysis is applied to analyse the industrial perception of hard skill and soft skill competencies, the competitiveness of managerial accounting diploma-4 students. To analyse the influence of hard skill and soft skill competencies on competitiveness, multiple linear regression analytical technique is used, with the formula: $\mathrm{Y}=\beta 0+\beta 1 \mathrm{X} 1$ $+\beta 2 \mathrm{X} 2+\mathrm{e}$; in which $\mathrm{Y}=$ competitiveness; $\mathrm{X} 1=$ hard skill competence; $X 2=$ soft skill competence; $\beta 0=$ constant; $\beta 1, \beta 2$, $=$ coefficients of regression; $\mathrm{e}=$ error. Classical assumption is needed to test regression model. Classical assumption test includes: data normality test, homoscedasticity test, linearity test, and multicolinearity test. Data normality is tested by carrying out One-Sample Kolmogorov-Smirnov Test; data homoscedasticity test uses Rho Spearman Test; data linearity test uses lack of fit test; and multicolinearity test is carried out by observing Tolerance or VIF result.

\section{RESULT AND DISCUSSION}

First, the result of classical assumption test as the prerequisite of multiple linear regression would be explained. The obtained result of linearity test which was carried out by doing lack of fit test was the relation between hard skill competence and competitiveness, Deviation from Linearity with Sig. 0,074. The relation between soft skill competence and competitiveness: Deviation from Linearity Sig. 0,345. Therefore, both of the variables' Deviation from Linearity are more than 0,05; which means either the relation between variables of hard skill competence and competitiveness or the relation between variables of soft skill and competitiveness are linear. Data normality test was carried out based on OneSample Kolmogorov-Smirnov Test. Asymp. Sig. (2-tailed) of hard skill competence $(0,107)$; soft skill competence $(0,101)$. Asymp. Sig. (2-tailed) of all variables are more than 0,05. Based on that description, all the variables are normally distributed. Homoscedasticity test was carried out by using Rho Spearman test. It was obtained the result: Sig. (2-tailed) of hard skill competence $(0,614)$, soft skill competence $(0,525)$. Both are more than 0,05 ; which means homoscedasticity was fulfilled. Multicolinearity test showed the tolerance of hard 
skill $(0,418)$ and soft skill $(0,418)$; both are more than 0,10 . Meanwhile VIF of hard skill competence $(2,392)$; and soft skill competence $(2,2492)<10$ which means that multicolinearity did not occur. Multiple linear regression model fulfills the prerequisite of classical assumption test; therefore this regression model is proper to be used for prediction.

\section{A. Analysis of Industrial Perception toward Hard Skill Competence of Managerial Accounting Diploma-4 Students at Bali State Polytechnic}

Variable of hard skill competence - based on 9 questions with various answers from 100 industries where the students do field work practice - there are some answers: very agree, agree, and neutral/doubtful. Then, these answers were summarized and resulted in answer frequency as follows: Question 1with the total score of 429; question 2 with the total score of 417; question 3 with the total score of 417 ; question 4 with the total score of 413; question 5 with the total score of 415; question 6 with the total score of 409; question 7 with the total score of 421 ; question 8 with the total score of 4440; and question 9 with the total score of 428 . The total of hard skill competence answers is with the total score of 3789 . These answers needs to be given meaning to know the position of the students' hard skill competence. The score used is the standard of 100. The standard of hard skill, soft skill, and competitiveness competencies assesment is with the criteria of very good 80100; good 70-79; fair 60-69; lack 50-59; and very lack 40-49. The total of the industries' answers is with the total score of 3789. The amount of the ideal score is $5 \times 9 \times 100=4.500$. Industrial assesment for hard skill competence $=(3789: 4500)$ $\mathrm{x} 100 \%=84,2 \%$. The assessment with numerical value standard is 84,2 . The assessment of hard skill competence of managerial accounting diploma-4 students, Bali State Polytechnic belongs to the assessment predicate in the 'very good' category.

\section{B. Analysis of Industrial Perception toward Soft Skill Competence of Managerial Accounting Diploma-4 Students at Bali State Polytechnic}

The variable of soft skill competence is with 9 questions and the answers are various from 100 industries where the students do field work practice. The answers are: very agree (very good), agree (good), and neutral/ doubtful (fair). Then, the answers were summarized and resulted in answers as follows: question 1 with the score of 447; question 2 with the score of 436; question 3 with the score of 416; question 4 with the score of 432; question 5 with the score of 440; question 6 with the score of 423; question 7 with the score of 427; question 8 with the score of 435; and question 9 with the score of 416. The total score of the industrial respondent answers related to soft skill competence is 3872 . The ideal score is $5 \times 9$ $\mathrm{x} 100=4500$. The assessment of the industries toward soft skill competence $=(3872: 4500) \times 100 \%=86,04 \%$. Based on the assessment with numerical value standard, it is 86,04 . The assessment of the soft skill competence of managerial accounting diploma-4 students belongs to the assessment predicate in 'very good' category.

\section{Analysis of Industrial Perception toward the Competitiveness of Managerial Accounting Diploma-4 Students at Bali State Polytechnic}

The variable of competitiveness has 18 questions with various answers from 100 industries where students do work field practice; the answers are very agree, agree, and neutral/ doubtful. Then, the score of the answers were summarized and resulted in answers as follows: question 1 with the score of 425; question 2 with the score of 416; question 3 with the score of 405; question 4 with the score of 419; question 5 with the score of 423; question 6 with the score of 421; question 7 with the score of 421 ; question 8 with the score of 399 ; question 9 with the score of 385 ; question 1.10 with the score of 382 ; question 1.11 with the score of 426; question 1.12 with the score of 429; question 1.13 with the score of 423 ; question 1.14 with the score of 432, question 1.15 with the score of 432; question 1.16 with the score of 427 ; question 1.17 with the score of 432; and question 1.18 with the score of 459 . The total is 7556. The ideal score is $5 \times 18 \times 100=9000$. The assessment of industries toward competitiveness is: $(7556$ : 9000$) \times 100 \%=$ $83,96 \%$. Based on the numerical value standard, the value is 83,96 . This assessment belongs to assessment predicate in 'very good' category. Therefore, the competitiveness of managerial accounting diploma-4 students at Bali State Polytechnic according to the perception of the industries is very good.

\section{Analysis on the Influence of Hard Skill Competence on the Competitiveness of Managerial Accounting Diploma-4 Students at Bali State Polytechnic}

The hypothesis proposed was: (H1) Hard skill competence gives positive and significant influence to the competitiveness of managerial accounting diploma-4 students at Bali State Polytechnic. The description of $t$ test result is presented in Table 1 to analyze the influence of hard skill competence on competitiveness.

Based on Table 1: Coefficients of t Test Result, for hard skill competence, it can be seen that $\mathrm{t}=4,602$ with Sig. $\mathrm{t}=$ 0,000 . The result of Sig. $t=0,000$ is less than 0,05 ; it means that the coefficient of hard skill competence is significant. This means that the hard skill competence gives significant influence toward competitiveness. The coefficient is positive; therefore, it can be interpreted that hard skill competence has positive influence for competitiveness. This can be interpreted that if hard skill competence increases, competitiveness will increase as well. Therefore, (H1): hard skill competence gives positive and significant influence to the competitiveness of managerial accounting diploma-4 students at Bali State Polytechnic has been proved or can be accepted. The results of this study are consistent with the findings that hard skills have a significant effect on performance $[3,5,18]$. 
TABLE I. COEFFICIENTS OF T TEST RESUlT

\begin{tabular}{|l|c|c|l|c|c|}
\hline \multirow{2}{*}{ Model } & \multicolumn{2}{|c|}{$\begin{array}{c}\text { Unstandardized } \\
\text { Coefficients }\end{array}$} & $\begin{array}{c}\text { Standardized } \\
\text { Coefficients }\end{array}$ & \multirow{2}{*}{ t } & \multirow{2}{*}{ Sig. } \\
\cline { 2 - 5 } & $\boldsymbol{B}$ & $\begin{array}{c}\text { Std. } \\
\text { Error }\end{array}$ & Beta & \\
\hline (Constant) & 9,549 & 4,182 & & 2,283 & 0,025 \\
\hline $\begin{array}{l}\text { Hard skill } \\
\text { competence }\end{array}$ & 0,761 & 0,165 & 0,377 & 4,602 & 0,000 \\
\hline $\begin{array}{l}\text { Soft skill } \\
\text { competence }\end{array}$ & 0,960 & 0,149 & 0,529 & 6,459 & 0,000 \\
\hline \multicolumn{7}{|c|}{$\begin{array}{l}\text { Sependent Variable: Competitiveness } \\
\text { Source: Output SPSS 24, 2020 }\end{array}$} \\
\hline
\end{tabular}

\section{E. Analysis of the Influence of Soft Skill Competence on the Competitiveness of Managerial Accounting Diploma-4 Students at Bali State Polytechnic}

The hypothesis proposed is: (H2) Soft skill competence gives positive and significant influence toward the competitiveness of managerial accounting diploma-4 students at Bali State Polytechnic. The result of $t$ test is presented the same as in Table 1 before. Based on Table 1: Coefficients of $t$ Test Result, in case of soft skill competence, it is known that $\mathrm{t}$ $=6,459$ with the Sig. $t=0,000$. The result of Sig. $t=0,000$ is less than 0,05 ; it means that the coefficient of soft skill competence is significant. This means that soft skill competence gives significant influence to competitiveness. The coefficient is positive so that it can be interpreted that soft skill competence gives positive influence to competitiveness. It can be interpreted that if soft skill competence increases, competitiveness will increase as well. Therefore, (H2): Soft skill competence gives positive and significant influence to the competitiveness of managerial accounting diploma-4 students at Bali State Polytechnic has been proved or can be accepted. The results of this study are also consistent with the findings that soft skills have a significant effect on performance $[3,5,16,18]$.

\section{F. Analysis of the Influence of Hard Skill and Soft Skill}

Competencies Simultaneously on the Competitiveness of

Managerial Accounting Diploma-4 Students at Bali State

Polytechnic

The hypothesis proposed is: (H3) Hard skill and soft skill competencies give positive and significant influence to the competitiveness of managerial accounting diploma-4 students at Bali State Polytechnic. The result of F test is shown in Table II below.

TABLE II. ANOVA OR F TEST RESULT

\begin{tabular}{|c|l|c|c|c|c|c|}
\hline \multicolumn{2}{|c|}{ Model } & $\begin{array}{c}\text { Sum of } \\
\text { Squares }\end{array}$ & df & $\begin{array}{c}\text { Mean } \\
\text { Square }\end{array}$ & F & Sig. \\
\hline \multirow{2}{*}{1} & Regression & 3375,820 & 2 & 1687,910 & 129,447 & $0,000^{\mathrm{b}}$ \\
\cline { 2 - 7 } & Residual & 1264,820 & 97 & 13,039 & & \\
\cline { 2 - 7 } & Total & 4640,640 & 99 & & & \\
\hline
\end{tabular}

a. Dependent Variable: Competitiveness

b. Predictors: (Constant), Soft skill competence, Hard skill competence
Based on Table II: Anova or F Test Result, it is known that $F=129,447$ with Sig. $F=0,000$. The result of Sig. $F=0,000$ is less than 0,05 ; it means the coefficient of hard skill and soft skill competencies is significant. This means hard skill and soft skill competencies simultaneously give significant influence to competitiveness. The result of hard skill and soft skill simultaneously gives positive influence to competitiveness by seeing that each variable coefficient is positive. This can be interpreted that if hard skill and soft skill competencies increase simultaneously, competitiveness will increase as well. Therefore, (H3): Hard skill and soft skill competencies give positive and significant influence to the competitiveness of managerial accounting diploma-4 students at Bali State Polytechnic has been proved or can be accepted. The results of this study are consistent with the findings which state that hard skills and soft skills have a significant effect on performance $[3,18]$.

\section{G. Analysis of Hard Skill and Soft Skill Competencies Integrated Model to Increase the Competitiveness of Managerial Accounting Diploma-4 Students at Bali State Polytechnic}

Based on the research result which shows that hard skill and soft skill competencies either partially or simultaneously give positive influence to the competitiveness of the graduates, and considering the needs of the industries, the integration of hard skill and soft skill competencies becomes really important. Students have to prepare themselves to compete before and after graduation to get jobs. The world of work nowadays needs qualified human resources that do not merely have hard skill competence but have soft skill competence as well. The success of the students is not merely determined by knowledge and hard skill, but as well by ability in managing their own selves and other people (soft skill).

Generally, the weakness in soft skill competence is the individual character, including the students. In case of the managerial accounting diploma-4 students, some important things are perceived weak or lack by the industries, such as the ability of the students in being creative or taking initiative and independence in doing tasks or working. Basically, these abilities can be honed and improved along with experiences. There are many ways to improve soft skill competence, such as learning by doing. Besides, soft skill competence can be honed and improved by joining training or seminar held by the students' senate. The way to improve soft skill is obviously by interacting and doing activities with other individuals. Joining student organizations is one way to interact with other people to hone soft skill competence. The department carries out the process of implementing the curriculum and make effort to give the best to the students by doing application in certain lecture subjects such as discussion, assignment presentation to train the ability to convey opinion and work independently. Thus, the students have to realize the importance of hard skill and soft skill competencies as an integration model that complements each other to make the graduates having better future and ready to work. If this is realized by every student, 
the graduates will be better, the students automatically will be superior in hard skill competence and have characters (soft skill competence) that are in line with the vision of the Accounting Department of Bali State Polytechnic: producing professional human resources in accounting.

\section{CONCLUSIONS}

Based on the result and discussion described, some conclusions are sucessfully drawn: (1) Perception of the industries to the hard skill competence of managerial accounting diploma-4 students at Bali State Polytechnic is very good. (2) Perception of the industries to the soft skill competence of managerial accounting diploma-4 students at Bali State Polytechnic is very good. (3) Perception of the industries to the competitiveness (measured from the work performance) of managerial accounting diploma-4 students at Bali State Polytechnic shows very good perception. (4) Hard skill competence gives positive and significant influence to the competitiveness of managerial accounting diploma-4 students at Bali State Polytechnic. (5) Soft skill competence gives positive and significant influence to the competitiveness of managerial accounting diploma-4 students at Bali State Polytechnic. (6) Hard skill and soft skill competencies simultaneously give positive and significant influence to the competitiveness of managerial accounting diploma-4 students at Bali State Polytechnic. (7) To increase the competitiveness of managerial accounting diploma-4 students at Bali State Polytechnic, the pattern of integration between hard skill and soft skill competencies has to complement each other, considering hard skill competence has to be balanced with soft skill competence based on the needs of the industries nowadays. With the integration pattern of combination between hard skill and soft skill competencies, it is expected that the competitiveness of the graduates of managerial accounting diploma-4 program will be superior and have characters.

\section{ACKNOWLEDGMENT}

This research could be conducted because of the financial support from the research fund of Bali State Polytechnic, in accordance with the DIPA Fund Research Implementation Agreement Letter for Fiscal Year 2020 Number: 1043/PL8/PG/2020. It was appreciated very much.

\section{REFERENCES}

[1] C.A.O. Assamoi, "Core Competencies Development among Science and Technology (S\&T) College Students and New Graduates,' American Journal of Educational Research, vol. 3, no. 9, pp. 1077 1084, 2015

[2] R.A. Sustermeister, People and Productivity. Second Edition. McGrow Hill Book Company, New York, pp. 2, 1969.

[3] A. Widjaja and E.J. Saragih, "Analysis on the Effect of Hard Skills, Intrapersonal and Interpersonal Skills toward the Performance of Nurses (A Case Study on the Alumni of Husada Hospital Nursing
Academy, Jakarta, Indonesia)," Quest Journals, Journal of Research in Business and Management, vol. 6, no. 5, pp. 31-38, 2018

[4] F.F. Patacsil and C.L.S. Tablatin, "Exploring the Importance of Sof and Hard Skills as Perceived by It Internship Students and Industry: A Gap Analysis," Journal of Technology and Science Education JOTSE, vol. 7, no. 3, pp. 347-368, 2017

[5] S. Anggiani, "Skill Influence on Employee Performance (Empirica Study of Frontlines three Star Hotels in Jakarta)," International Journal of Management and Applied Science, vol.3, no. 12, pp. 14-18, 2017.

[6] I. Nuryana and T. Triwahyudiyanto, "Pengaruh Softskill Dan Hardskil Terhadap Kinerja Siswa Prakerin Smk Modern Al-Rifa'Ie (Studi pada Siswa Prakerin SMK Modern Al-Rifa'ie Gondanglegi)," JPIG (Jurnal Pendidikan dan Ilmu Geografi), vol. 1, no. 1, 2016

[7] W. Wahyuni, Pengaruh Hard Skill dan Soft Skill Terhadap Kinerja Pegawai pada Dinas Pendidikan Provinsi Sulawesi Selatan (Doctoral dissertation, Universitas Islam Negeri Alauddin Makassar), 2016.

[8] D. Hodges and N. Burchell, "Business Graduate Competencies: Employers' Views on Importance and Performance," Asia-Pacific Journal of Cooperative Education, vol. 4, no. 2, pp. 16-22, 2003.

[9] J.W. Slocum and D. Hellriegel, Principles of Organizational Behavior SouthWestern, United States, pp. 25, 2009.

[10] S. Shivanjali, "Softskills Training Versus Hard Skills Training," International Journal in Multidisciplinary and Academic Research (SSIJMAR), vol. 1, no. 3, 2010

[11] H. Hadiyanto, N. Noferdiman, M. Moehamin and $\mathrm{Y}$. Yuliusman, "Assessing Students and Graduates Soft Skills, Hard Skills and Competitiveness," People: International Journal of Social Sciences, vol. 3, no. 2, pp. 1885-1906, 2017.

[12] B. Schulz, "The Importance of Soft Skills: Education Beyond Academic Knowledge," Nawa Journal of Language and Communication, pp. 46-154, 2008

[13] A.H.M. Adnana, S. Ramalingamb, N. Ilias and T. Mt. Tahir, "Acquiring and Practicing Soft Skills: A Survey of Technical-Technologica Undergraduates at a Malaysian Tertiary Institution," Procedia-Social and Behavioral Sciences, vol. 123, pp. 82-89, 2014.

[14] Z. Aimao, "Peer Assessment of Soft Skills and Hard Skills," Journal of Information Technology Education: Research, vol.11, pp.155-168, 2012.

[15] L. Nikitina and F. Furuoka, "Sharp Focus on Soft Skills: a Case Study of Malaysian University Students' Educational Expectations,' Educational Research for Policy and Practice, vol.11, pp. 207-224, 2012

[16] S.B.S. Ahmad, "Soft Skills Level of Malaysian Students at a Tertiary Institution: a Comparative Case Study Based on Gender, Area of Residence and Type of Schhools," International Journal of Asian Social Science, vol. 3, no. 9, pp. 1929-1937, 2013

[17] R. Ibrahim, A. Boerhannoeddin and K.K. Bakare, "The effect of soft skills and training methodology on employee performance," European Journal of Training and Development, 2017.

[18] N.S. Siahaan and H. Sihombing, "Pengaruh Hard Skill dan Soft Skill terhadap Kinerja Karyawan PT Telkom Sumatra," Jurnal Plans. Penelitian Ilmu Manajemen \& Bisnis, vol. 12, no. 2, pp. 143-153, 2017.

[19] E. Pang, M. Wong, C.H. Leung and J. Coombes, "Competencies for Fresh Graduates' Success at Work: Perspectives of employers," Industry and Higher Education, vol. 33, no.1, pp. 55-65, 2019.

[20] T. Sumiharjo, Penyelenggaraan Pemerintah Daerah Melalui Pengembangan Daya Saing Berbasis Potensi Daerah. Bandung: Penerbit Fokusmedia, 2008.

[21] J. Pallant, SPSS Survival Manual: A Step by Step Guide to Data Analysis Using SPSS for Windows". McGraw-Hiel and Open University Press, Berkshire, pp. 15, 2007 